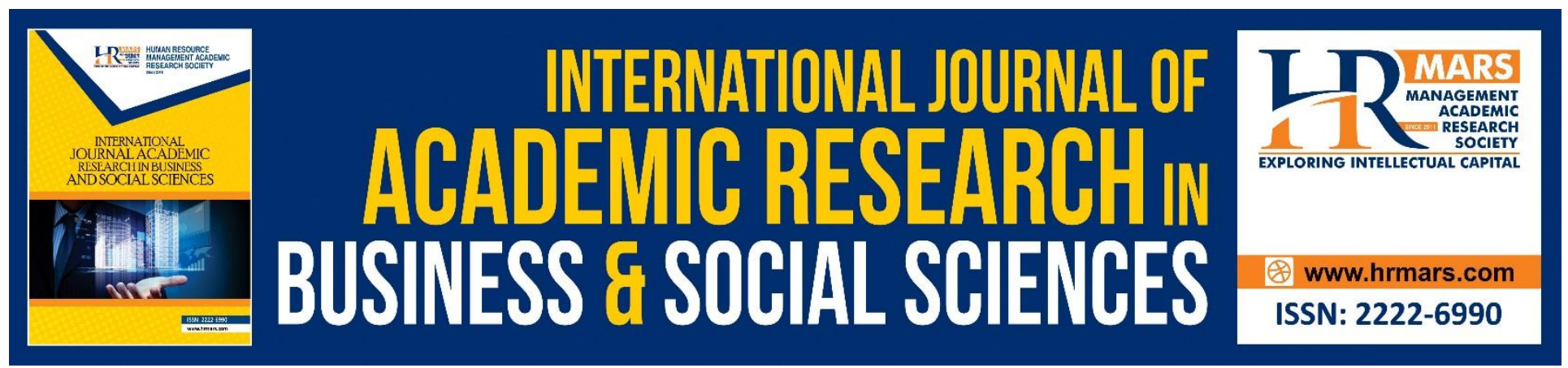

\title{
The Impact of Service Quality on Customers' positive Word of Mouth towards Food Truck Business in Malaysia
}

Haliza Mohd Said, Ahmad Faizal Md Sukarno, Zaid Abdul Razak, Siti Bayaah Ahmad, Safiah Rashid

To Link this Article: http://dx.doi.org/10.6007/IJARBSS/v8-i9/4872

DOI: $\quad 10.6007 /$ IJARBSS/v8-i9/4872

Received: 09 August 2018, Revised: 30 August 2018, Accepted: 13 Sept 2018

Published Online: 15 Sept 2018

In-Text Citation: (Said, Sukarno, Razak, Ahmad, \& Rashid, 2018)

To Cite this Article: Said, H. M., Sukarno, A. F. M., Razak, Z. A., Ahmad, S. B., \& Rashid, S. (2018). The Impact of Service Quality on Customers' positive Word of Mouth towards Food Truck Business in Malaysia. International Journal of Academic Research in Business and Social Sciences, 8(9), 1919-1940.

Copyright: (C) 2018 The Author(s)

Published by Human Resource Management Academic Research Society (www.hrmars.com)

This article is published under the Creative Commons Attribution (CC BY 4.0) license. Anyone may reproduce, distribute, translate and create derivative works of this article (for both commercial and non-commercial purposes), subject to full attribution to the original publication and authors. The full terms of this license may be seen

at: http://creativecommons.org/licences/by/4.0/legalcode

Vol. 8, No. 9, September 2018, Pg. 1919 - 1940

http://hrmars.com/index.php/pages/detail/IJARBSS

JOURNAL HOMEPAGE

Full Terms \& Conditions of access and use can be found at http://hrmars.com/index.php/pages/detail/publication-ethics 


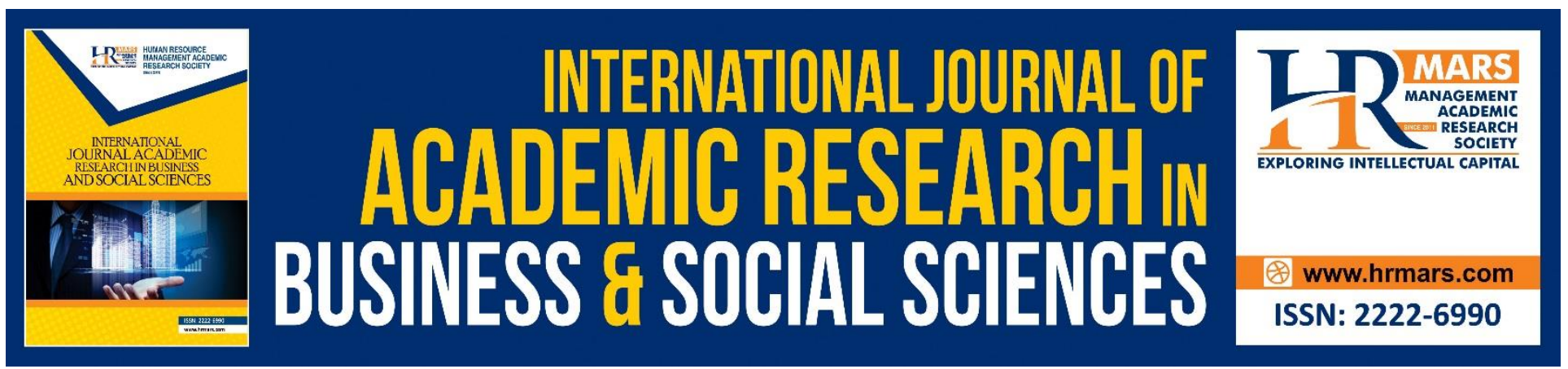

\title{
The Impact of Service Quality on Customers' positive Word of Mouth towards Food Truck Business in Malaysia
}

\author{
Haliza Mohd Said*, Ahmad Faizal Md Sukarno, Zaid Abdul Razak, \\ Siti Bayaah Ahmad, Safiah Rashid \\ UNITAR International University, Malaysia \\ Email: lizasaid@unitar.my
}

\begin{abstract}
This study investigates the elements which contribute to service quality for customers' positive words of mouth towards the food trucks business in Klang Valley, Malaysia. The study examines whether the quality dimensions included in the SERVQUAL model apply in a local food trucks environment, specifically in Klang Valley. A total of 199 respondents have been surveyed using a structured questionnaire with 30 Likert-type scale adapted from the Parasuraman's SERVQUAL instrument (1988) and the original list of service quality dimensions provided by Zeithaml et al. (1990). The findings show that dimensions such as courtesy and competence of the personnel, communication and transactions, knowing and understanding the customer, accuracy and speed of service have a significant importance to customers positive words of mouth while availability of tangible dimension were revealed to have a low relationship in comparison to other dimensions suggesting that food trucks owners should pay more attention to the dimensions of tangible awareness that will enhance customer positive word of mouth. This study also supports the argument in past literature that has deliberated quality as an important predictor of customer behavior.
\end{abstract}

Keywords: Service Quality, Positive Words of Mouth, Service Improvement, Food Truck Business

\section{Introduction}

The foodservice industry has evolved over the past few decades from merely a meal providing facility to an augmented combination of service associated features. These features are emphasized to satisfy the complementary needs of its customers. This notion of satisfaction is mainly attributed to the quality of service. Hence a lot of probing has been going on for the past few decades to rationalize and prove a direct relationship between the two.

Food truck business is increasingly popular in Malaysia. Some of us are unaware that our country has enjoyed mobile food delivery in various forms over the years. Some of the traditional 
mobile food choices in the past are very popular mobile food sellers have become "roti man". The man will ride his bike or bike from house to house with honking is a famous horn and pulls everyone from housewives to young children. Most Malaysians still remember the excitement of listening to the voice and seeing "roti man". The man would have everything from bread and cakes to my "muruku" and various types of sweets and crackers. Other mobile food operators are "chendol men". This is something that will be remembered by every seventies, eighties and nineties child. There is nothing like a refreshing bowl of "chendol" on a sunny day. It is a daily after-school treatment. As time passes, Malaysians see more complex setups, such as the popular "yong tau foo", popular "tau foo fa" and "lok-lok" vendors (Blazevic, 2016).

In the United States over the last few years, it seems that food trucks have taken over food places in many cities. This modern food truck provides a variety of eclectic, gourmet options for a very reasonable price. Like Malaysia, mobile food is not a new concept in the United States either. From chuck trucks from the old west to hot dogs in New York City, fast, cheap, food on the road has become part of our country's history (Emergent for the National Restaurant Association, 2012). "Some of the best food Americans eat may come from a food truck" . is a prediction from The Economist (2010) has become true. Gourmet trucks across the country are at the forefront of modern dining, serving affordable and delicious fare that rarely can be found at the neighborhood sandwich shop. In its 2011 research report on street vending entitled Streets of Dreams, the Institute for Justice explained how street vendors, including food-truck owners, are creating jobs, satisfying customers and generally making their communities safer and more interesting places to live.

Parallel with above notion, service quality is becoming a major part in business practices (Mei, Dean \& White, 1999). While service quality has been highlighted as the vital element in the process of fulfilling the customers' needs, service encounter is another element which contributes to the customers' evaluation on the services given. This is supported by the statement of Chapman and Lovell (2006), "the service encounter is at the heart of the service provided by an organization to the customer". In addition, service encounter is widely recognized as the time-frame during which a customer directly interacts with service providers (Surprenant \& Solomon, 1987). Many theories and models have been established in this regard. Zeithaml, Parasuraman and Berry (1988) proposed an empirically derived method called Servqual to be used by service organizations to improve quality. The Servqual scale was employed widely to measure the service quality in different industries of service sector including restaurants (Bojanic \& Rosen, 1994; Fu, 1999). This methodology was based around five key dimensions. All of the dimensions have significant impact of varying degrees on customer satisfaction.

Several studies have been conducted to analyze the degree of impact of service quality dimensions on the customer behavioral intention. However, the difference of the population sample, their cultural values, environment, per-capita income and emotions play a significant role in evaluating these dimensions (Bojanic \& Rosen, 1994; Fu, 1999). Therefore, this study is conducted to analyze the service quality impact on a customer of a Food Trucks in Klang Valley area. 
INTERNATIONAL JOURNAL OF ACADEMIC RESEARCH IN BUSINESS AND SOCIAL SCIENCES

Vol. 8, No. 9, Sept. 2018, E-ISSN: 2222-6990 @ 2018 HRMARS

\section{Research Problem}

When lifestyle changes and eating becomes more common, many customers want new taste and experience. Food trucks have become a growing trend in modern KL's food offerings. These mobile eateries serve up interesting fare from fusion dishes to traditional delicacies that are prepared from inside a food truck. Nowadays, the concept of food trucks is getting more and more attractive. Due to the popularity of Food Trucks, it will be interesting to know the issues of customer behavior and service quality perceptions. There are several types of research exploring the key attributes that influence customer behavior and service quality perceptions on Food Truck organizations, which are of major importance to food service operators. Often, the quality seen has been seen as one of the most important factors that determines customer's attention and positive intention of word-ofmouth behavior in the service industry (Andaleeb \& Conway, 2006).

According to Zeithaml et al. (1996, p. 33), behavioral intentions "signal whether customers will remain with or defect from the company". Behavioral intentions can be categorized as favorable or unfavorable. Favorable behavioral intentions include positive word of mouth (saying positive things and recommending the service to others), paying a price premium, spending more money with the company, and remaining loyal. As a result, the understanding of different customer needs is important for food service operators to maintain and expand their markets in this aggressive and competitive environment. While many studies prove the importance of service quality management in the hotel industry, there is a relatively limited inspection of the actual determinants and the exact impact on the quality of service built in this environment (Wilkins et al., 2007).

There has been variable support for the validity of the SERVQUAL model in the hotel service industry (Wilkins et al., 2007). Akan (1995) investigated the applicability of the SERVQUAL model in the Turkish hospitality industry and identified seven dimensions: (1) Courtesy and competence of the personnel; (2) Communication and transactions; (3) Tangibles; (4) Knowing and understanding the customer; (5) Accuracy and speed of service; (6) Solutions to problems; and (7) Accuracy of hotel reservations. From these 7 dimensions, this study will develop and test empirically the conceptual model of the relationship between these construct. According to the proposed model, 5 dimensions of, Akan (1995) SERVQUAL model will be used for this study and examine the impact on positive word of mouth. The 5 dimensions are Courtesy and competence of the personnel; Communication and transactions; Tangibles; Knowing and understanding the customer; and finally, Accuracy and speed of service.

The general situations of food trucks are probably surrounded with numerous of problems based on the conditions of the staffs that are still new with the food trucks. Despite the differences in the scale of operation, organizational structure and business strategies among food trucks, the common objective is to utilize and maximize their resources to achieve a high level of profits through the efficient and excellent quality of service. This will result to customer satisfaction and eventually to customers' positive word of mouth. On this matter, although the food trucks have been categorized by their different types and class of operation, it cannot be denied that these food trucks are providing the same services which then giving customers options for their service preferences. At 
INTERNATIONAL JOURNAL OF ACADEMIC RESEARCH IN BUSINESS AND SOCIAL SCIENCES

Vol. 8, No. 9, Sept. 2018, E-ISSN: 2222-6990 (C) 2018 HRMARS

this stage, it has produced a critical question with the extent on how customers perceive the services delivered by food trucks. In other words, do their perception on the food trucks is different? This is the issues which need to be investigated.

\section{Research Objectives}

This study is to assess customers' behavioral intention on the service quality dimension customers' positive word of mouth towards food truck business in Klang Valley. In order to support the main objective, five intermediate objectives had been highlighted:

R01: To examine the significant influence between courtesy and competence of the personnel and customers' positive word of mouth.

RO2: To examine the significant influence between communication and transactions and customers' positive word of mouth.

R03: To examine the significant influence between tangibles and customers' positive word of mouth.

RO4: To examine the significant influence between knowing and understanding the customer and customers' positive word of mouth.

R05: To examine the significant influence between accuracy and speed of service and customers' positive word of mouth.

\section{Research Questions}

This study is aim to answer the following research questions:

RQ1: Does courtesy and competency of the personnel have an influence on customers' positive word of mouth?

RQ2: Does communication and transaction have an influence on customers' positive word of mouth?

RQ3: Does tangibles of food trucks have an influence on customers' positive word of mouth?

RQ4: Does knowing and understanding the customers have an influence on customers' positive word of mouth?

RQ5: Does accuracy and speed of service have an influence on customers' positive word of mouth?

\section{Significance of Study}

This study aims to provide a better understanding of the customer behavioral intention impact on the service quality dimension of food trucks establishments in Klang Valley area. Klang Valley area is well developing area in Selangor with many food trucks hot spots and food festival are available in the area that is why it is chosen for the study. The understanding of customer behavior intention especially on positive word of mouth can assist food trucks operators and practitioners when they develop marketing strategies and enable them to select the most salient attributes to attract and retain customers. Furthermore, a theoretical model of customer behavioral intention in this study will help to provide a useful framework for future research regarding customer positive 
INTERNATIONAL JOURNAL OF ACADEMIC RESEARCH IN BUSINESS AND SOCIAL SCIENCES Vol. 8, No. 9, Sept. 2018, E-ISSN: 2222-6990 @ 2018 HRMARS

word of mouth and service quality in the foodservice industry. This significant is particularly important due to the limited empirical studies on customer positive word of mouth in Klang Valley area.

\section{Literature Review \\ Underpinning Theory}

The theoretical underpinning of this study is based on the SERVQUAL model of the restructured version from Akan (1995). To reflect these expectations, SERVQUAL is a valuable tool as a concept, and also with respect to the dimensions of service which it proposes. However, this scale is not necessarily generic or universal. It should be modified both for the specific service situation and for the environmental context within which it is used, to make it a more valuable tool (Akan, 1995). Akan (1995) mentioned, this finding is in line with the findings of the SERVQUAL study, where the dimensions competence and courtesy also were combined along with credibility and security under assurance. This makes the understanding and knowing the customer similar to empathy dimension of SERVQUAL in this context. In parallel with that, Akan's demonstrated that customers attach great importance to tangibles related to the room and other public areas of the building, and food and beverages item. Akan (1995) has applied the SERVQUAL model in the four stars hotels and suggested that competence and courtesy along with assurance were most important factors affecting the perception of quality. Akan (1995) in his study of dimensions of service quality in Istanbul hotels found that " users of Turkish four and five-star hotels may expect to receive friendly, courteous, hygienic and expert service but without special personalized attention" ( Akan, 1995, p.39).

\section{Independent Variables (Perceived Service Quality)}

Zeithaml \& Bitner (2003) and Bitner \& Hubert (1993) defined service quality as a comparison of what the customers feel a service provider should offer (expectations). Oliver (1993) and Bitner (1995) state that service quality perceived by customers, is the difference between customers' perceptions and expectations of service quality. In marketing literature, Parasuraman et al. (1985) have defined service quality as the extent to which a service meets or exceeds customer expectations. Presbury, Fitzgerald \& Chapman (2005) emphasize that it is very important to provide service quality that meets the expectations of customers.

Service quality is the most studied subject in service marketing (Fisk et al., 1993), and the SERVQUAL scale introduced by Parasuraman et al. (1998) has mastered the conceptualization and measurement of service quality construct (Brady et al., 2002). Despite its widespread adoption across all sectors of the service, attention should be paid in adjusting SERVQUAL to certain settings. SERVQUAL is a useful starting point, not a final solution, to access and improve service quality (Parasuraman et al., 1991). Therefore, SERVQUAL can be adequately supplemented with filtering material to capture contextual information and to include additional theoretical research framework. Service quality represents an evaluation formed by comparing expectations and perceived performance (Ha and Jang, 2010; Barber et al., 2011). 
With the rise in the service economy, the success of service providers now depends on their ability to provide customer-centric services (Gustafsson and Johnson, 2003). The importance of perceived service quality (Edvardsson, 1998, 2005) and customer experience (Walter et al., 2010) is widely acknowledged. With the growing tendency of outsourcing elements of the service delivery process, a customer often engages with several complementary service providers (Laing and Hogg, 2008; Tax et al., 2013). The delivery and consumption of services have changed dramatically with profound consequences for all the actors involved (Bitner et al., 2000, 2010; Lin and Hsieh, 2011; Rayport and Jaworski, 2004; Sandström et al., 2008).

Furthermore, some studies have reported that the SERVQUAL scale is not universal because the precision of service quality appears to depend on the type of service being examined (Carman, 1990; Babakus and Boller, 1992). There is a variable support for validity of the SERVQUAL model in the hotel services industry (Wilkins et al., 2007). Akan (1995) investigates the application of the SERVQUAL model in the Turkish hospitality industry and identifies seven dimensions: (1) Skilled and competent staffing; (2) Communications and transactions; (3) Tangibles; (4) Knowing and understanding customers; (5) Accuracy and speed of service; (6) Problem solving; and (7) The accuracy of hotel reservations.

\section{Dependent Variables (Positive Word of Mouth)}

In the literature, in general, positive behavioral intentions have been the focus of study. For instance, positive behavioral intentions have been investigated within the scope of conative loyalty in the loyalty model developed by Oliver (1997). Among these positive intentions, re-purchasing or WOM intentions are especially researched (Alcaniz et al., 2005; Han and Back, 2008; Han et al., 2009; Küçükergin and Dedeog `lu, 2014; Prayag and Ryan, 2012; Zabkar et al., 2010). Westbrook (1987, p. 261) has stated that WOM is composed of "informal communications directed at other consumers about the ownership, usage or characteristic of particular goods and services and/or their sellers". Anderson (1998, p. 6) states that WOM "includes relating pleasant, vivid, or novel experiences; recommendations to others; and even conspicuous display". Re-visiting intentions can be defined as the intentions of consumers to re-prefer same product, brand, place or region in the future (Zeithaml et al., 1996).

According to Zeithaml et al. (1996), behavioral intention "signal whether the customer will remain or defect from the company". The intention of behavior can be categorized as favorable or unfavorable. The intentions of encouraging behavior include positive words (saying positive things and recommending services to others), paying premium prices, spending more money with the company, and staying true. In the service industry, behavioral intentions are a possibility that customers will repurchase from service providers in the near future and support service providers with positive comments on the positive word-of-mouth (Hutchinson et al., 2011).

Word-of-mouth intention is an important tool for international businesses and regions (Bone, 1995), because businesses often cannot bring their products and services, such as destinations or hotel businesses, to the customers' doorstep, as product and service production are synchronous and 
INTERNATIONAL JOURNAL OF ACADEMIC RESEARCH IN BUSINESS AND SOCIAL SCIENCES Vol. 8, No. 9, Sept. 2018, E-ISSN: 2222-6990 @ 2018 HRMARS

on-site, although they try to advertise themselves in the best way possible. In addition, Ha and Jang (2010) have pointed out that WOM is one of the most effective tools in the service sector. Thus, it can be stated that positive behavioral intentions of people who have experienced a business is quite important for the hotel industry.

Word-of-mouth is defined as an exchange, flow of information, communication, or conversation between two individuals. There is but a single author (Haywood, 1989) who considered word-of-mouth as formal conversation. Other authors agree that word-of-mouth is an informal and noncommercial conversation. The term "informal" makes reference to something that is not organized in an official manner (Rey-Debove \& Rey, 2007). In addition, WOM communications are occasionally defined as post purchase behaviours. Word-of-mouth is one of the most influential and reliable approaches for transmitting information among customers in the marketplace and in consumers' decision-making (Cheung and Thadani, 2012; Xu and Chan, 2010). Word-of-mouth is able to instill the brand message in the mind of consumers, and it leads to a better understanding and impression of the brand as a whole. It has been found to have a strong positive influence on customers' perception of brand image and consequently on their purchase intention (Jalilvand and Samiei, 2012). In addition, word-of-mouth has also been reported to have a positive impact on brand awareness (Kiss and Bichler, 2008), brand trust (Ha, 2004), brand purchase intention (East et al., 2008) and consumer-based brand equity (Bambauer-Sachse and Mangold, 2011).

\section{Relationships of Variables}

Many studies have investigated the relationship between perceived quality and behavioral intentions. Parasuraman et al. (1991) found positive relationships between service quality and willingness to recommend companies. Boulding et al. (1993) reports that the service quality as a whole has a negative correlation with misleading behaviors and transitions, but is positively related to readiness to recommend. On the other hand, Cronin and Taylor (1992) found that service quality had no significant effect on repurchase intentions in any of the four industries they studied (banking, insect control, dry cleaning, and fast food). However, Zeithaml et al. (1996) found that the service quality as a whole has a negative correlation with the behavior of complaints and change behavior, but positively related to the willingness to pay more and loyalty. Bei and Chiao (2001) found that high levels of service were seen to only have an indirect positive impact on consumer loyalty (through satisfaction). Cronin et al. (2000) found that the relationship between perceived service quality and behavioral intent was specialized in the industry; In particular, they find that service quality has a direct impact on consumer behavioral intentions in fast food service, spectator sports, participating sports, and entertainment, but not in remote transportation services and healthcare services. The author also reports that the effect of service quality is either directly and indirectly (through satisfaction and value seen). Dagger and Sweeney (2006), report that functional quality and technical quality significantly influence behavioral intentions. Chow et al. (2007) found that high service levels were associated with frequent customer support within the restaurant industry.

Jayawardhena and Farrell (2011) mentioned that service quality is positively related to customer satisfaction which again is positively related to retail customers' behavioral intentions. Choudhury 
(2011) explored the relation between service quality and WOM with a small sample size of customers and banks. In this regard, it would be interesting to study the link between the individual dimensions of service quality and WOM with a large-scale study with a large representative sample size and greater number of banks. The relationship at the level of the individual dimensions of these two constructs could be explored and it would be of both theoretical and managerial interest to see how service quality and WOM are related at the level of individual dimensions, rather than the perspective of their overall assessments, in order to gain an in-depth insight into this issue. This study hopes to add to the research on service quality and its influence on customers' behavioral intentions by exploring the relationship at the level of the individual dimensions of both service quality and WOM. Linking both constructs at their dimensional level increases the diagnostics of explaining customers' propensity for WOM.

In the food service industry, there are a few studies that have examined the relationship between the service quality and positive word mouth. Baker and Crompton (2000), find positive service quality related to the willingness to pay more money and customer loyalty. Alexandris et al. (2002), found that four of the five dimensions of SERVQUAL had a significant effect on word-of-mouth communication and that all five dimensions had a significant effect on buying back intention. Therefore, the following hypotheses are proposed.

Previous studies by Akan (1995) found that other factor had a significant impact to behavioral intention, specifically positive word-of-mouth; that is (1) Courtesy and competence of the personnel; (2) Communication and transactions; (3) Tangibles; (4) Knowing and understanding the customer; (5) Accuracy and speed of service;. I. Goyette et al., (2010) mentioned word of mouth would allow the organization to measure what is said about it (content), the scope of what is said (intensity), and the attitude of the browser towards the organization.

\section{Research Framework}

Based on the research questions and research objectives highlighted, a simple framework has been developed. The theoretical framework shows the relationship between the service quality dimension and customers satisfaction. 
INTERNATIONAL JOURNAL OF ACADEMIC RESEARCH IN BUSINESS AND SOCIAL SCIENCES

Independent Variables

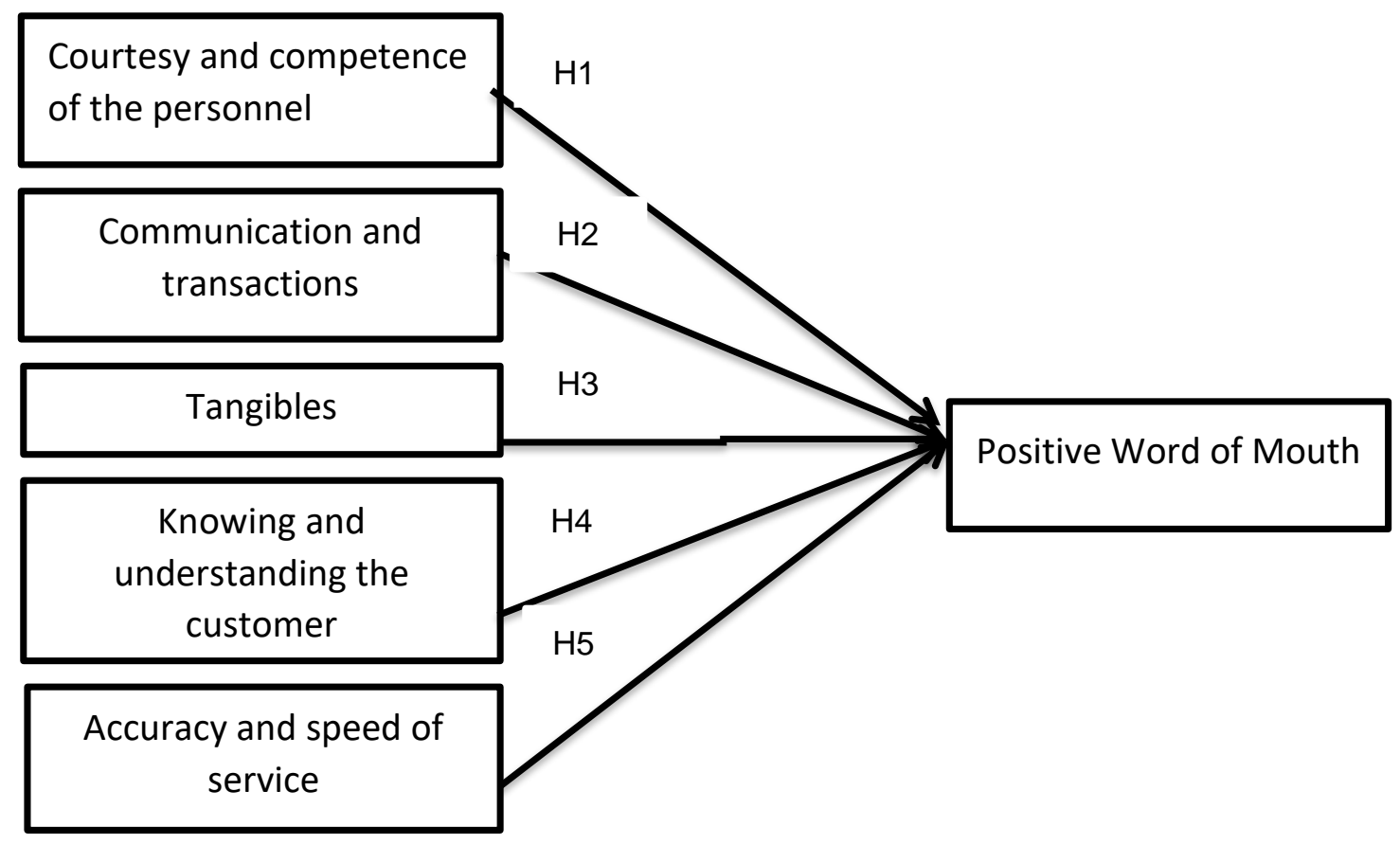

Figure 2.1: Theoretical Framework

Based on the above framework, the following hypothesis are constructed to test the following relationships:

H1 : There is a significant influence between courtesy and competence of the personnel and customers' positive word of mouth.

H2 : There is a significant influence between communication and transactions and customers' positive word of mouth.

H3 : There is a significant influence between tangibles and customers' positive word of mouth.

H4: There is a significant influence between knowing and understanding the customer and customers' positive word of mouth.

H5 : There is a significant influence between accuracy and speed of service and customers' positive word of mouth.

\section{Research Methodology}

Research Design

As this study seeks to identify the factors that contribute to service quality for customers' positive words of mouth towards the food trucks business, thus a quantitative experimental design has been conducted to analyze the relationship between independent and dependent variables. Questionnaires are considered as the most appropriate method for data collection process. The 
INTERNATIONAL JOURNAL OF ACADEMIC RESEARCH IN BUSINESS AND SOCIAL SCIENCES

Vol. 8, No. 9, Sept. 2018, E-ISSN: 2222-6990 @ 2018 HRMARS

questionnaires were in the form of closed-ended questions. The arrangement of the questionnaires was set very simple and easy for the respondent to understand.

Population and Unit of Analysis

A set of questionnaire has been used to obtained respondents' opinion about the service quality on food trucks business in Klang Valley. The sampling frame for this study is the food truck customers in Klang Valley. The population of this study is the customers who visit and use food provided by food trucks within a certain period of time. Convenience sampling was applied in this context because it is based on the most accessible response chosen because it saves time and save cost and we choose those respondents who dine at the food trucks in the Klang Valley area.

In this study, a sample size was selected to represent the targeted population because the targeted population size was too large. According to Krejcie and Morgan (1970) Table sample size, the sample size that were used is more than 200 and less than 250 respondents. The respondents were requested to fill up the questionnaire and return it back immediately. As a result, a total of 199 questionnaires were collected.

Measurement and Instrument

Self-structured questionnaires have been designed and modified with the help of previous research. The self-administered questionnaire enables researchers to gather all the complete data from respondents within a short period of time. Researchers can explain any doubt from respondents at the scene (Sekaran, 2003). Closed questions were selected when designing the style and type of questionnaire format. The Likert scale is chosen as a measure for this study because of its reliability and ability to provide more data compared to other scales, especially when measuring people's attitudes and opinions on different aspects (Babbie, 2007). In addition, the research instrument should be straight forward for respondents to answer questions consistently to obtain useful data and responses (Sekaran, 2003).

The questionnaire comprised five (7) sections (Section A, B, C, D, E, F, and G) with section (A) looking at the respondent's demographic profile. Section (B) assessed with the courtesy and competence of personnel of food trucks, while Section (C) assessed the communication and transactions of food trucks. Section (D) assessed the tangibles of food trucks; section (E) assessed the knowing and understanding the customer of food trucks; section (F) assessed the accuracy and speed of service of food trucks and finally section $(G)$ assessed the customer positive word of mouth on the overall food trucks.

Data Collection Technique

For this study quantitative primary data was collected through a questionnaire survey adapted from Perran Akan instrument (1995). Zikmund (2010) assessed the survey as a research technique where information was obtained from population target samples using questionnaires. Self-structured questionnaires have been designed and modified with the help of previous research distributed to 
INTERNATIONAL JOURNAL OF ACADEMIC RESEARCH IN BUSINESS AND SOCIAL SCIENCES

Vol. 8, No. 9, Sept. 2018, E-ISSN: 2222-6990 (C) 2018 HRMARS

consumers' who visits food trucks in the Klang Valley area. The questionnaire was designed with closed-ended items. The dimensions in dimensions are measured on Likert 5-point scale.

Pilot Study

Pilot study was conducted with 30 respondents at a food truck eatery located in Klang valley. The Pilot study was conducted to check on the reliability of the instrument.

Table 3.9: Reliability test for pilot study

\begin{tabular}{lll}
\hline Variable & No. of Items & $\begin{array}{l}\text { Cronbach's } \\
\text { Alpha }\end{array}$ \\
\hline Courtesy and Competence of personnel & 4 & .717 \\
Communication and Transactions & 4 & .759 \\
Tangibles & 5 & .770 \\
Knowing and Understanding the customer & 4 & .897 \\
Accuracy and Speed of service & 5 & .813 \\
Customer Positive Word of Mouth & 6 & .935 \\
\hline
\end{tabular}

From the reliability analysis result for 30 respondents as shown in Table 3.9, all factor including independent and dependent variables were found to be good reliability. Then, the analysis is used to identify the cronbach's alpha value. The result shows that the cronbach's alpha for courtesy and competency of personnel was 0.717 . While the value for communication and transactions was 0.759 , tangibles value was at 0.770 , knowing and understanding the customer was 0.897 , accuracy and speed of service was at 0.813 and lastly, customer positive word of mouth value was at 0.935 . According to Nunnally (1978) cronbach's alpha value of greater than 0.7 is consider acceptable. The pilot study cronbach's alpha all indicates value of greater than 0.7 shown in table 3.10. Thus, identify consistency of the questionnaire and also validity to identify the reliability for the all the variables are acceptable.

Data Analysis Technique

Once all the questionnaires have been collected, the data then were coded and keyed in for analysis using a Statistical Package of Social Science (SPSS) version 23. The analytical methods included the descriptive statistics to analyzed demographic information. Cronbach's alpha to test the reliability of the instrument, factor analysis, correlation analysis, regression and the means of variables to analyze the relationship between variables.

\section{Data Analysis and Findings}

Demographic Profile of Respondents

Frequency distribution was collected from the demographic profile. The collected frequency was computed to analyze the demographic profile data, which consist of ethnicity, gender, marital status, education level, occupation, frequency of visit in a month, amount spent on every visit and household monthly income. 
INTERNATIONAL JOURNAL OF ACADEMIC RESEARCH IN BUSINESS AND SOCIAL SCIENCES Vol. 8, No. 9, Sept. 2018, E-ISSN: 2222-6990 (C) 2018 HRMARS

Table 4.1: Respondent's Profile

\begin{tabular}{|c|c|c|c|}
\hline Demographic & Category/Class & Frequency & Percent \% \\
\hline \multirow{4}{*}{ Ethnicity } & Malay & 113 & 56.5 \\
\hline & Chinese & 52 & 26.0 \\
\hline & Indian & 28 & 14.0 \\
\hline & Others & 7 & 3.5 \\
\hline \multirow[t]{2}{*}{ Gender } & Male & 106 & 53.0 \\
\hline & Female & 94 & 47.0 \\
\hline \multirow{3}{*}{ Marital status } & Single & 110 & 55.0 \\
\hline & Married & 87 & 43.5 \\
\hline & Others & 3 & 1.5 \\
\hline \multirow{4}{*}{ Education Level } & Certificate & 12 & 6.0 \\
\hline & Diploma & 103 & 51.5 \\
\hline & Bachelor Degree & 61 & 30.5 \\
\hline & Others & 24 & 12.0 \\
\hline \multirow{4}{*}{ Occupation } & Students & 61 & 30.5 \\
\hline & Government Servant & 55 & 27.5 \\
\hline & Private Servant & 78 & 39.0 \\
\hline & Others & 6 & 3.0 \\
\hline \multirow{3}{*}{$\begin{array}{l}\text { Frequency of visit } \\
\text { in a month }\end{array}$} & Once & 84 & 42.0 \\
\hline & Twice & 92 & 46.0 \\
\hline & More than 3 times & 22 & 11.0 \\
\hline \multirow{4}{*}{$\begin{array}{l}\text { Amount spent on } \\
\text { every visit }\end{array}$} & Less than RM20 & 40 & 20.0 \\
\hline & RM20 to RM50 & 137 & 68.5 \\
\hline & RM50 to RM100 & 18 & 9.0 \\
\hline & More than RM100 & 5 & 2.5 \\
\hline \multirow{5}{*}{$\begin{array}{l}\text { Household monthly } \\
\text { income }\end{array}$} & Below RM1500 & 18 & 9.0 \\
\hline & RM1500 to RM3000 & 61 & 30.5 \\
\hline & RM3001 to RM5000 & 84 & 42.0 \\
\hline & RM5001 to RM10000 & 30 & 15.0 \\
\hline & More than RM10000 & 7 & 3.5 \\
\hline
\end{tabular}


INTERNATIONAL JOURNAL OF ACADEMIC RESEARCH IN BUSINESS AND SOCIAL SCIENCES

Vol. 8, No. 9, Sept. 2018, E-ISSN: 2222-6990 @ 2018 HRMARS

\section{Normality Test}

Normality test has been tested for dependent variables which are customer positive word of mouth determine normal distribution.

Figure 4.1: Normality Positive Word of Mouth

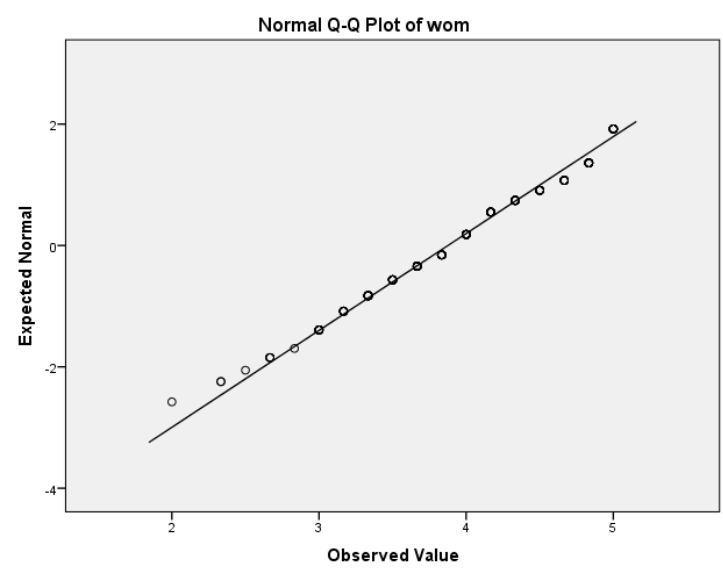

Based on figure 4.1, customer positive word of mouth shows more in a straight line and therefore, it is considered as a normal distribution for the dependent variable.

\section{Correlation Analysis}

This analysis is used if we need to describe the strength and direction of the relationship between two continuous variables. Correlation and regression analysis are related as both deal with relationships among variables.

Table 4.4: Rule of thumb on Correlation Coefficient Size

\begin{tabular}{lc}
\hline Strength of Association & Correlation Coefficient range \\
\hline High & $0.6-0.78$ \\
Moderate & $0.4-0.6$ \\
Low & below 0.4 \\
\hline
\end{tabular}

Source: Hair et al. (2006)

The correlation coefficient is a measure of linear association between two variables and the values are always between -1 and +1 . A correlation coefficient of +1 indicates that two variables are perfectly related in a positive linear sense; a correlation coefficient of -1 indicates that two variables are perfectly related in a negative linear sense, and a correlation coefficient of 0 indicates that there is no linear relationship between the two variables. Neither regression nor correlation analyses can be interpreted as cause-and-effect relationships. It only indicates on what extent variables are associated with each other. 
INTERNATIONAL JOURNAL OF ACADEMIC RESEARCH IN BUSINESS AND SOCIAL SCIENCES Vol. 8, No. 9, Sept. 2018, E-ISSN: 2222-6990 (C) 2018 HRMARS

Table 4.5: Correlations Matrix

\begin{tabular}{|c|c|c|c|c|c|c|c|}
\hline & & 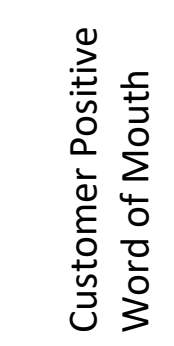 & 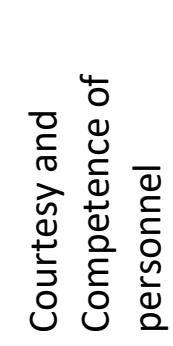 & 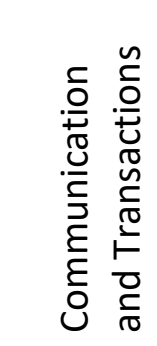 & $\begin{array}{l}\frac{\tilde{y}}{0} \\
\frac{0}{00} \\
\frac{0}{\sigma 0} \\
⺊\end{array}$ & 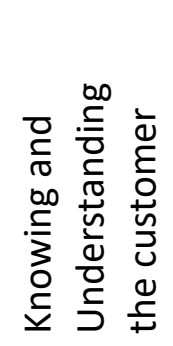 & 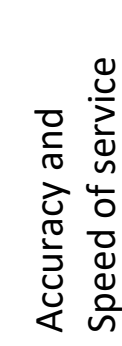 \\
\hline $\begin{array}{l}\text { Customer } \\
\text { Positive }\end{array}$ & $\begin{array}{l}\text { Pearson } \\
\text { Correlation }\end{array}$ & 1 & $.588^{* *}$ & $.636^{* *}$ & $.607^{* *}$ & $.734^{* *}$ & $.817^{* *}$ \\
\hline Word of & Sig. (2-tailed) & & .000 & .000 & .000 & .000 & .000 \\
\hline Mouth & $\mathrm{N}$ & 199 & 199 & 199 & 199 & 199 & 199 \\
\hline Courtesy and & $\begin{array}{l}\text { Pearson } \\
\text { Correlation }\end{array}$ & $.588^{* *}$ & 1 & $.614^{* *}$ & $.530^{* *}$ & $.664^{* *}$ & $.561^{* *}$ \\
\hline Competence & Sig. (2-tailed) & .000 & & .000 & .000 & .000 & .000 \\
\hline & $\mathrm{N}$ & 199 & 199 & 199 & 199 & 199 & 199 \\
\hline Communicati & $\begin{array}{l}\text { Pearson } \\
\text { Correlation }\end{array}$ & $.636^{* *}$ & $.614^{* *}$ & 1 & $.705^{* *}$ & $.706^{* *}$ & $.650^{* *}$ \\
\hline $\begin{array}{l}\text { on and } \\
\text { Trancactions }\end{array}$ & Sig. (2-tailed) & .000 & .000 & & .000 & .000 & .000 \\
\hline & $\mathrm{N}$ & 199 & 199 & 199 & 199 & 199 & 199 \\
\hline & $\begin{array}{l}\text { Pearson } \\
\text { Correlation }\end{array}$ & $.607^{* *}$ & $.530^{* *}$ & $.705^{* *}$ & 1 & $.734^{* *}$ & $.656^{* *}$ \\
\hline Iangıbles & Sig. (2-tailed) & .000 & .000 & .000 & & .000 & .000 \\
\hline & $\mathrm{N}$ & 199 & 199 & 199 & 199 & 199 & 199 \\
\hline $\begin{array}{l}\text { Knowing and } \\
\text { Understandi }\end{array}$ & $\begin{array}{l}\text { Pearson } \\
\text { Correlation }\end{array}$ & $.734^{* *}$ & $.664^{* *}$ & $.706^{* *}$ & $.734^{* *}$ & 1 & $.760^{* *}$ \\
\hline ng the & Sig. (2-tailed) & .000 & .000 & .000 & .000 & & .000 \\
\hline customer & $\mathrm{N}$ & 199 & 199 & 199 & 199 & 199 & 199 \\
\hline Accuracy and & $\begin{array}{l}\text { Pearson } \\
\text { Correlation }\end{array}$ & $.817^{* *}$ & $.561^{* *}$ & $.650^{* *}$ & $.656^{* *}$ & $.760^{* *}$ & 1 \\
\hline $\begin{array}{l}\text { Speed of } \\
\text { service }\end{array}$ & Sig. (2-tailed) & .000 & .000 & .000 & .000 & .000 & \\
\hline & $\mathrm{N}$ & 199 & 199 & 199 & 199 & 199 & 199 \\
\hline
\end{tabular}

From the correlation Table 4.7, it shows the relationship between variables. We can therefore conclude that:

I. There is a significant relationship between courtesy and competence of the personnel and customer positive word of mouth. $(r=0.588, \mathrm{P}=0.000)$ as there is moderate degree of strength $(r=0.588)$. 
II. There is a significant relationship between communication and transactions and customer positive word of mouth. ( $r=0.636, P=0.000)$ as there is high degree of strength $(r=0.636)$.

III. There is a significant relationship between tangibles and customer positive word of mouth. ( $r=0.607, P=0.000)$ as there is high degree of strength ( $r=0.607)$.

IV. There is a significant relationship between knowing and understanding the customer and customer positive word of mouth. $(r=0.734, P=0.000)$ as there is high degree of strength $(r=0.734)$.

V. There is a significant relationship between accuracy and speed of service and customer positive word of mouth. $(r=0.817, P=0.000)$ as there is high degree of strength $(r=0.817)$.

A correlation coefficient of customer positive word of mouth $(r=1)$ indicates that all the independent variables are perfectly related in a positive linear sense.

\section{Regression Analysis}

Regression analysis involves identifying the relationship between a dependent variable and one or more independent variables. A model of the relationship is hypothesized, and estimates of the parameter values are used to develop an estimated regression equation. Various tests are done to determine if the model is satisfactory after which an estimated regression equation can be used to predict the value of the dependent variable given values for the independent variables. Regression analysis is done to determine the significant value which represented by the $P$ value $<0.05$ to reject null hypothesis.

Table 4.6: Regression analysis result

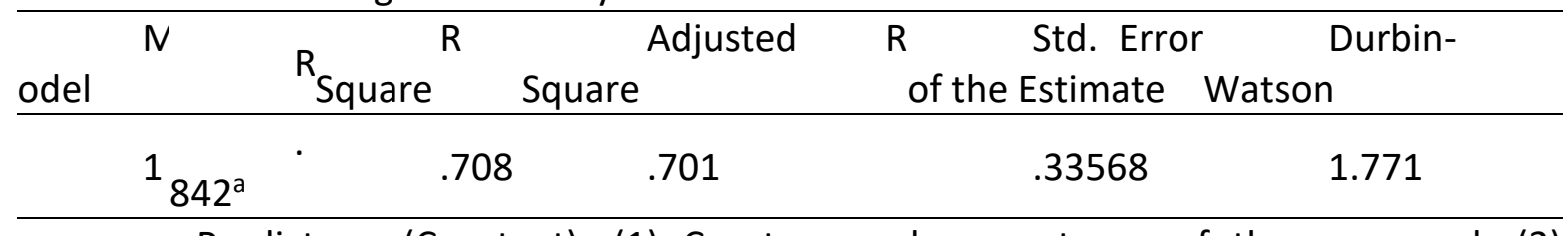

a. Predictors: (Constant), (1) Courtesy and competence of the personnel; (2) Communication and transactions; (3) Tangibles; (4) Knowing and understanding the customer; (5) Accuracy and speed of service

b. Dependent Variable: Positive Word of Mouth

Based on the table 4.6 it shows that courtesy and competence of the personnel; communication and transactions; tangibles; knowing and understanding the customer; accuracy and speed of service explained $71 \%$ of the variance of the customer positive word of mouth. 
INTERNATIONAL JOURNAL OF ACADEMIC RESEARCH IN BUSINESS AND SOCIAL SCIENCES Vol. 8, No. 9, Sept. 2018, E-ISSN: 2222-6990 @ 2018 HRMARS

Table 4.7: ANOVA result between Positive Word of Mouth and Service Quality ANOVA $^{\mathrm{a}}$

\begin{tabular}{|c|c|c|c|c|c|}
\hline Model & Sum of Squares & $d f$ & Mean Square & $\mathrm{F}$ & Sig. \\
\hline Regression & 52.781 & 5 & 10.556 & 93.680 & $.000^{b}$ \\
\hline Residual & 21.748 & 193 & .113 & & \\
\hline Total & 74.529 & 198 & & & \\
\hline
\end{tabular}

a. Dependent Variable: Positive Word of Mouth

b. Predictors: (Constant), (1) Courtesy and competence of the personnel; (2) Communication and transactions; (3) Tangibles; (4) Knowing and understanding the customer; (5) Accuracy and speed of service

One-Way ANOVA indicates whether there are significant differences in the mean score on the customers' positive word of mouth. Based on the table 4.7 the result indicate that customers' positive word of mouth have a significant difference with Courtesy and competence of the personnel; Communication and transactions; Tangibles; Knowing and understanding the customer; Accuracy and speed of service by the factor of positive words of mouth at the 0.01 significance degree.

Based on table 4.8, the result indicate that courtesy and competence of the personnel have no significant relationship with customers' positive word of mouth $(P=0.059, \beta=0.103)$, while communication and transactions have no significant relationship with customers' positive word of mouth ( $P=0.2, \beta=0.08)$. Tangibles have no significant with customers' positive word of mouth $(P=0.762, \beta=-0.019)$. Knowing and understanding the customer have a significant relationship with customers' positive word of mouth $(P=0.017, \beta=0.180)$. Accuracy and speed of service have a significant relationship with customers' positive word of mouth ( $P=0.000, \beta=0.583$ ). In addition, between the two significant variables accuracy and speed is the most preferred towards customers' positive word of mouth with $\beta=0.583$, followed by knowing and understanding the customer.

Table 4.8: Coefficient result between Service Quality and Positive Word of Mouth

\begin{tabular}{|c|c|c|c|c|c|c|}
\hline \multirow{2}{*}{ Model } & \multicolumn{2}{|c|}{$\begin{array}{l}\text { Unstandardized } \\
\text { Coefficients }\end{array}$} & \multirow{2}{*}{$\begin{array}{r}\text { Standardized } \\
\text { Coefficients } \\
\text { Beta }\end{array}$} & & \multirow{2}{*}{$\mathrm{t}$} & \multirow{2}{*}{ Sig. } \\
\hline & B & Error & & & & \\
\hline (Constant) & .059 & .193 & & 04 & .3 & .761 \\
\hline $\begin{array}{l}\text { Courtesy and competence of the } \\
\text { personnel }\end{array}$ & .111 & .059 & .103 & 897 & 1. & .059 \\
\hline Communication and transactions & .087 & .068 & .080 & 286 & 1. & .200 \\
\hline Tangibles & -.018 & .061 & -.019 & .303 & - & .762 \\
\hline $\begin{array}{l}\text { Knowing and understanding the } \\
\text { customer }\end{array}$ & .177 & .073 & .180 & 412 & 2. & .017 \\
\hline Accuracy and speed of service & .631 & .068 & .583 & 335 & 9. & .000 \\
\hline
\end{tabular}

a. Dependent Variable: Positive Word of Mouth 
In addition, table 4.8 also shows the t-value that indicate courtesy and competence of personnel $(t=1.897)$, communication and transactions $(t=1.286)$ and tangibles $(t=0.303)$ which this three variables indicate $t$-value less than 1.96. Meanwhile, the $t$-value for knowing and understanding the customer $(t=2.412)$ and accuracy and speed of service $(t=9.335)$ both variables have $t$-value binger than 1.96. The result will furthermore be explained in Chapter 5 on the hypothesis finding.

\section{Conclusion}

\section{Discussion on Analysis of Result}

This study differs in some aspects from the previous study's findings that positive word of mouth is a result of the service quality dimension by encompassing Courtesy and competence of the personnel; Communication and transactions; Tangibles; Knowing and understanding the customer; Accuracy and speed of service Interpretation of dining experience. Unlike previous studies on quality on behavior, this study looks at the quality dimensions from the customer's perspective word of mouth. This study shows the difference existence between Courtesy and competence of the personnel; Communication and transactions; Tangibles; Knowing and understanding the customer; Accuracy and speed of service of customers positive word of mouth with regard to the crucial attributes of the five quality facets during their visit experiences at the food trucks business.

Although the results of correlation coefficient of customer positive word of mouth $(r=1)$ indicates that all the independent variables are perfectly related in a positive linear sense, but the logistic regression analyses showed that not all quality attributes were critical to customers' positive words of mouth. Availability of tangible dimension were revealed have a low relationship in comparison to other dimensions suggesting that food trucks owners should pay more attention to the dimensions of tangible awareness will enhance customer positive word of mouth, which is consistent with previous studies. With regard to Courtesy and competence of the personnel; Communication and transactions; Knowing and understanding the customer; Accuracy and speed of service were of significant importance to customers; positive words of mouth.

Reiteration of Hypothesis Testing

H1: There is a significant relationship between courtesy and competence of the personnel and customer positive word of mouth.

The standardize beta and T-value of the courtesy and competence of the personnel is 0.103 and 1.897 respectively. The coefficient of courtesy and competence of the personnel is significant to explain customers' positive words of mouth at the 0.01 significance level. Therefore, $\mathrm{H} 1$ is supported

H2: There is a significant relationship between communication and transactions and customer positive word of mouth.

T-value of communication and transactions is 1.286 , which fulfills the 0.01 significance degree. The coefficient value of 0.080 indicates the communication and transaction positively influence customers' positive words of mouth. Therefore, $\mathrm{H} 2$ is supported.

H3: There is a significant relationship between tangibles and customer positive word of mouth. 
INTERNATIONAL JOURNAL OF ACADEMIC RESEARCH IN BUSINESS AND SOCIAL SCIENCES Vol. 8, No. 9, Sept. 2018, E-ISSN: 2222-6990 @ 2018 HRMARS

The standardize beta and T-value of the tangibles is -0.019 and -0.303 respectively. The coefficient of tangibles is significant to explain negative influence customers' positive words of mouth at the 0.01 significance level. It is the strongest negative variables. Therefore, H3 is supported

H4: There is a significant relationship between knowing and understanding the customer and customer positive word of mouth.

T-value of knowing and understanding the customer is 1.286 , which fulfills the 0.01 significance degree. The coefficient value of 0.080 indicates the knowing and understanding the customer positively influence customers' positive words of mouth. It is the second strongest positive variables. Therefore, $\mathrm{H} 4$ is supported.

H5: There is a significant relationship between accuracy and speed of service and customer positive word of mouth.

The standardize beta and T-value of the accuracy and speed of service is 0.583 and 9.335 respectively. The coefficient of accuracy and speed of service is significant to explain customers' positive words of mouth at the 0.01 significance level. It posts the strongest positive impact among all the variables. Therefore, $\mathrm{H} 5$ is supported.

\section{Limitations}

Despite its management implications, some of the study limitations need to be addressed. This study only focuses on the relatively small food truck business selected from a limited geographical area, so the yield distribution is insufficient. While it is not anticipated that the findings would be very different, it would be helpful to expand this research throughout the country to improve the availability of the findings. Examples of the other locations such as UNESCO sites or heritage tourist spots could be of interest for the town council to identify the impact of service quality on customers' positive word of mouth towards food truck business in order to attract more tourists to the sites.

\section{Future Research and Recommendation}

This study supports the theoretical views of the quality and the previous behavior by identifying the essential characteristics in determining customers' positive words of mouth. The primary discovery is that Courtesy and competence of the personnel; Communication and transactions; Knowing and understanding the customer; Accuracy and speed of service do contribute to the customers' positive words of mouth. This study also supports the argument in literature considered quality is an important predictor of customer behavior. Therefore, more studies on the relationship between customer behavior and perceived quality are needed to cross confirming findings from multiple directions. From a methodological point of view, quality research and future satisfaction should benefit from developing a more robust measurement by incorporating the three key quality factors and the unique nature inherent in the food service industry.

Future research should examine the behavior of consumers of food and services in more detail and should include a detailed survey of food service workers and fair prices. Specific areas of interest are how consumers determine the nature of food as far as consumers are knowledgeable about food 
truck business and what consumer elements identify as the most important factor that causes them to act differently in the food truck business if there is any difference. It is also interesting to know how the food service provider, in this case, food truck owners understand the difference between their own food culture and other people's food culture from the inside perspective? Additionally, it is important to know cross-cultural factors and their impact on consumer consumption and behavior.

Recommendation for future studies will also include other food truck business segments, such as limited services, high-end and mid-range food truck businesses. Future studies comparing the quality of the essential attributes of limited service, top-class food trucks can better assist truck food owners to fit each segment's needs.

\section{Conclusion}

In conclusion, this study provides an understanding of the significant relationship between the two variables, i.e., the quality of service against the positive words of the customer. The authors' hope that the findings of this study can be explained satisfactorily customers' positive words of mouth and that food trucks should focus on the major elements which are tangible; courtesy and competence of the personnel; communication and transactions; knowing and understanding the customer; accuracy and speed of service to enhance customers' positive behavior. The results also show that the service quality dimensions of the food truck characteristics are most important to customers. Dimension restaurant attributes include all employees' personal relationships with customers including whether they are fast, courteous, knowledgeable, and neat in appearance, helpful, attentive, and understand the needs of customers.

Furthermore, a theoretical model of customer behavioral intention in this study will help to provide a useful framework for future research regarding customer positive word of mouth and service quality in the foodservice industry. This significant is particularly important due to the limited empirical studies on customer positive word of mouth in Klang Valley area. In addition, this study also reveals that there is a need for comprehensive research to be done. It is believed that through this comprehensive research will reveal the exact reason why people eat at a particular establishment. There may be various reasons for such purposes as business relations, family rallies or anything else, but this will still be an assumption until further investigation is made. It is also believed that it may give a deeper picture of the factors that restaurant owners and full-service managers need to emphasize on the number of their offerings.

\section{Corresponding Author}

Haliza Mohd Said

UNITAR International University

Malaysia

Email: lizasaid@unitar.my 
INTERNATIONAL JOURNAL OF ACADEMIC RESEARCH IN BUSINESS AND SOCIAL SCIENCES

Vol. 8, No. 9, Sept. 2018, E-ISSN: 2222-6990 (C) 2018 HRMARS

\section{References}

Akan, P. (1995). Dimensions of service quality: A study in Istanbul. Managing Service Quality 5 (6): 39-43.

Babbie, E., Mouton, J., Vorster, P. \& Prozesky, B. (2006). The practice of social research. Cape Town: Oxford University Press.

Bitner, M. J. \& Hubbert, A. R. (1993), Encounter satisfaction vs overall satisfaction vs quality the customer's voice, in: Service quality new directions in theory and practice, Rust, R. T. \& Oliver, R. L. (Eds.), Sage Publications, Newbury Park, USA, pp. 71-93

Bitner, M. J. (1995), Building service relationships: It's all about promises, Journal of Academic Marketing Science, Vol. 23, No. 4, pp. 246-251

Bojanic, D. C., \& Rosen, L.D (1994), "Measuring Service Quality in Restaurants: An Application of the SERVQUAL Instrument", Hospitality Research Journal, 18(1), 4-14

Brady, M. K., Cronin Jr, J. J., \& Brand, R. R. (2002). Performance-only measurement of service quality: a replication and extension. Journal of Business Research, 55(1), 17- 31.

Hair, J. F., W. C. Black, B. J. Babin, R. E. Anderson, and R. K. Tatham. (2006). Multivariate data analysis. 6th Edition. Upper Saddle River, $\mathrm{n}$ j: Pearson Prentice Hall.

Fisk, R. P., Brown, S. W., and Bitner, Mary Jo. Tracking the Evolution of the Services Marketing Literature. Journal of Retailing 69[1], 61-103. 1993.

Oliver, R. L. (1993), A conceptual model of service quality and service satisfaction: Compatible goals, different concepts, Advances in Services Marketing and Management, Vol. 2, pp. 65-85

Parasuraman, A., Berry, L.L. and Zeithaml, V.A. (1991), "Refinement and reassessment of the SERVQUAL scale", Journal of Retailing, Vol. 67 No. 4, pp. 420-450.

Parasuraman, A., Zeithaml, V. A. and Berry, L. L. (1985). A conceptual model of service quality and its implications for future research. Journal of Marketing, 49 (4): 41-50.

Parasuraman, A., Zeithaml, V. A. and Berry, L. L. (1988). SERVQUAL: a multiple-item scale for measuring consumer perceptions of service quality. Journal of Retailing. 64 (1): 12-40

Presbury, R., Fitzgerald, A. \& Chapman, R. (2005), Impediments to improvements in service quality in luxury hotels, Management service quality, Vol. 15, No. 4, pp. 357- 373 
INTERNATIONAL JOURNAL OF ACADEMIC RESEARCH IN BUSINESS AND SOCIAL SCIENCES

Vol. 8, No. 9, Sept. 2018, E-ISSN: 2222-6990 (C) 2018 HRMARS

Sekaran, U. (2003). Research methods for business: Askill building approach(4th ed.). New York: JohnWiley

Westbrook, Robert. A. (1987), "Product/Consumption-based Affective Responses and Postpurchase Process", Journal of Marketing Research, Vol. 24 (August), pp. 258-270.

Zeithaml, V.A. (2000), Service quality, profitability, and the economic worth of customers: what we kno and what we need to learn, Journal of the Academy of Marketing Science, Vol.28, No. 1, pp.67-86.

Zeithaml, V. \& Bitner, M. (2003), Service marketing: Integrating customer focus across the firm, (3rd ed.), McGraw-Hill Irwin, New York, USA

Zeithaml, V. A., Berry, L.L. \& Parasuraman, A. (1996). The behavioural consequences of service quality. Journal of Marketing Management, 60(No. April), 31-46.

Zikmund, B.J., Couper, M.P., Singer, E., Levin, C.A., Fowler, F.F., Ziniel, S., Ubel, P.A., Fagerlin, A. (2010). The Decision Study: A Nationwide Survey of United States Adults Regarding 9 Common Medical Decisions. Vol 30, Issue 5_suppl, pp. 20 - 34. Retrieved from https://doi.org/10.1177/0272989X09353792 